\title{
Geotechnical Properties of Saw Dust Ash Stabilized Southwestern Nigeria Lateritic Soils
}

\author{
Thompson Henry Tolulope Ogunribido \\ Department of Geology, Adekunle Ajasin University, Akungba, Akoko, Nigeria \\ crossref http://dx.doi.org/10.5755/j01.erem.60.2.986
}

(received in December, 2011, accepted in June, 2012)

\begin{abstract}
This research was carried out with an intention to evaluate the effects of saw dust ash on the geotechnical properties of soil from three locations in Southwestern Nigeria. Tests that were performed on three samples, A, B and C, dealt with consistency limits, specific gravity, compaction, California bearing ratio, unconfined compressive strength and shear strength. These tests were conducted at both non-stabilized and stabilized states by adding 2, 4, 6, 8 and $10 \%$ of saw dust ash. The results show that saw dust ash has improved geotechnical properties of the soil samples: maximum dry density increases from 1403 to1456 $\mathrm{Kg} / \mathrm{m}^{3}$ and 1730 to $1785 \mathrm{~kg} / \mathrm{m}^{3}$, optimum moisture content increases from 23.6 to $28.2 \%$ and 26.2 to $29.2 \%$, unconfined compressive strength - from 101.4 to 142.14 and 154.97 , shear strength - from 50.92 to $71.07 \mathrm{kN} / \mathrm{m}^{2}$ and 77.49 to $105.99 \mathrm{kN} / \mathrm{m}^{2}$ for samples A and B, respectively. Saw dust ash is therefore found to be an effective stabilizer for lateritic soils.

Preface. Road failure is a common problem in Nigeria which is due to low materials application quality in road building. This article has a mission of providing some information to the road building industry that geotechnical properties of the materials they use can be improved by adding a stabilizer such as saw dust ash.

Key words: Saw dust ash, geotechnical properties, lateritic soil, stabilization
\end{abstract}

\section{Introduction}

Lateritic soils are often found in tropical regions which are typical of distinct wet and dry seasons. Lateritic soils are often used in tropical regions for road building. Failures of highway pavements have been common on the Nigerian highway system since the colonial period (Jegede 2000). Failures on Nigeria highways are generally due to poor geotechnical properties of the underlying soils which constitute the base or sub grade material for the entire road configuration. Necessity to improve soil properties for road building has resulted in the use of various stabilizers (Amu et al. 2010). The application of chemicals such as Portland cement, lime, fly ash, saw dust ash, etc. or the combination of them often results in the transformation of soil index properties which may involve the cementation of particles (Amadi 2010). Lateritic soils are widely employed as imported filling material for the prepared sub grade on different kinds of road projects. To enhance durability of such roads, lateritic soils are often stabilized. Some studies have been carried out on geotechnical properties of lateritic soil using stabilizers (Okunade 2010, Oloruntola et al. 2008, Amu et al 2011, Okafor and Okonkwo 2009). Generally, soil stabilization is to improve engineering performance of soil.

The purpose of this study is to determine the effect of saw dust ash stabilizer on geotechnical properties of lateritic soils. This will encourage the use of saw dust ash as stabilizer in road building.

\section{Materials and Methods.}

The materials used in this study are lateritic soil samples, saw dust ash, and water.

Saw dust ashes are loose particles or wood chippings obtained by sawing hard wood into standard useable sizes and then burned. Clean saw dust without a large amount of bark has proved to be satisfactory because of low organic content. Saw dust was obtained from a Sawmill in Akure, Ondo State, Nigeria. After its collection, it was spread on the 
ground and air dried to facilitate its burning. Saw dust was burnt to ashes and was then sieved through a BS sieve of $75 \mu \mathrm{m}$ to get very fine ash. Then it was stored in an air tight container to prevent moisture loss and any form of contamination. Saw dust ash generally contained little lime and a big combination of silica, alumina and silica.

Three disturbed consolidated lateritic soil samples A, B and C were collected from three different pits in Akure, Nigeria. The pits were excavated by diggers and shovels and soil samples were collected into nylon bags at an average depth of $1 \mathrm{~m}$ to obtain true representative samples. The natural moisture content was determined immediately in the Engineering Geology Laboratory of the Federal University of Technology, Akure. Soil samples were air dried for two weeks before other analysis. Soil properties to be determined were natural moisture content, specific gravity, liquid limits, plastic limits, plasticity index, linear shrinkage, unconfined compressive strength, compaction, California bearing ratio (CBR), and shear strength. The compaction tests involved the application of load on the soil samples which were divided into 5 layers in a mould $\left(0.002124 \mathrm{~m}^{3}\right)$ and were subjected to 55 blows of $44.5 \mathrm{~N}$ Rammar falling from a height of $0.46 \mathrm{~m}$. This was first done without adding any saw dust ash and only thereafter saw dust ash of 2, 4, 6, 8 and $10 \%$ was added to determine its influence on both the index and geotechnical properties of the tested soil. The CBR and unconfined compressive strength were determined by means of standard procedures of BS 1377 of 1991 .

\subsection{Location and Geology of the Study Area}

The study area lies within longitude $7^{0} 18 \mathrm{~N}$ and $7^{0} 16 \mathrm{~N}$ North of the Equator and between latitudes $5^{0} 09^{1} \mathrm{E}$ and $5^{\circ} 11.5^{1} \mathrm{E}$ of the Greenwich meridian (Fig. 1). The study area lies within the Pre - Cambrian crystalline rocks of the Basement complex of Southwestern Nigeria ( Rahamam 1976 and 1989). Predominant rock types in the study area are: Charnokites, granite gneiss and migmatitic rocks. In some places of the study area these rocks have undergone deep weathering.

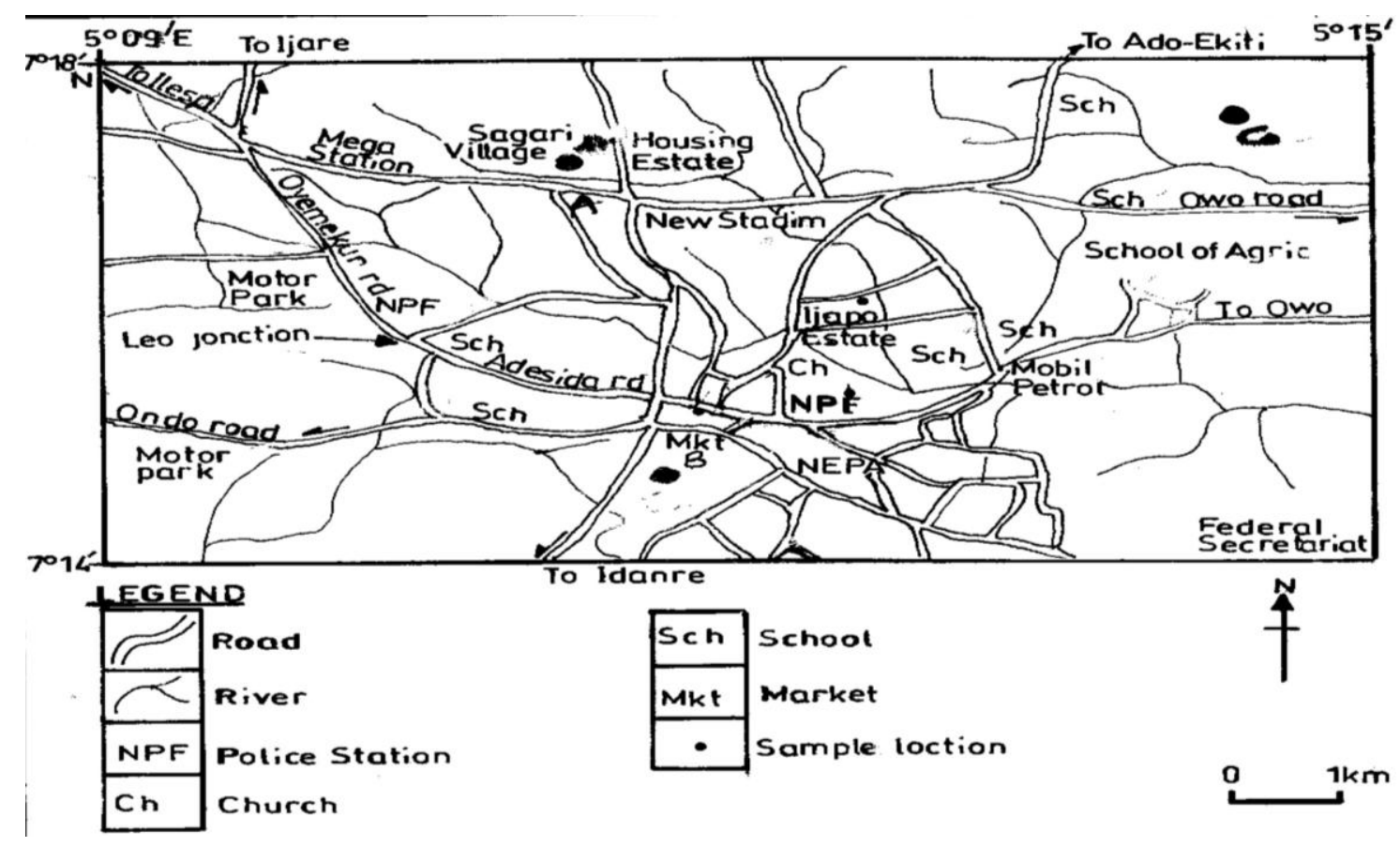

Fig. 1 .

Location map of the study area

\section{Results and Discussion}

Results of the preliminary tests are presented in Tables 1 and 2, engineering property tests are presented in Tables 3 and 4.

Consistency limits. The liquids limit decreased from 55.3 to $44.2 \%$ and 52.0 to $37.4 \%$ in samples A and $\mathrm{B}$, respectively, when saw dust ash was raised from 0 to $10 \%$ for both samples. This can be considered to be a result of the addition of saw dust ash, which has less affinity for water and yields a decrease limit of liquid. The consistency limit of sample $\mathrm{C}$ cannot be determined.
Specific gravity. The specific gravity of sample A was 2.77, for sample B - 2.74, for sample C - 2.65 which are within the range of 2.6 and 3.4 reported for lateritic soils. The mixing two of saw dust ash of specific gravity 2.11 resulted in the reduction of the unit weight of lateritic - saw dust ash mixtures compared to the lateritic soil alone which is an improvement for the property of the soil for various geotechnical uses.

Compaction characteristics. Dry unit weight in various soils mixed with saw dust ash decreases with an increase in the percentage of the saw dust ash, while the optimum moisture content increases and the amount of saw dust ash in the mixture increases from 
0 to $10 \%$. A decrease in the dry unit weight may be lower specific gravity of the saw dust ash, while an increase in the optimum moisture content may be as a result of water needed to be hydrated. Characteristics of soil in the study area are controlled by the index properties which are in line with Gidigasu (1983).

California Bearing Ratio (CBR). The asphalt institute (1962) recommended a CBR of $7 \%$ to $20 \%$ and from 0 to $7 \%$ for highway sub base and sub grade material, respectively. Based on this, sample A is a good sub grade material, sample B can be used as sub base, while sample $\mathrm{C}$ is not good for engineering purposes. This shows that load bearing capacity of soil sample $\mathrm{C}$ is very low and may result in failure when it is used for construction purposes

Unconfined Compressive Strength. According to Das (2000) consistency of a clayey soil can be determined as follows: $0-25 \mathrm{kN} / \mathrm{m}^{2}$ indicates very soft, $25-50 \mathrm{kN} / \mathrm{m}^{2}$ is soft, $50-100 \mathrm{kN} / \mathrm{M}^{2}$ is medium soft, and $100-50 \mathrm{kN} / \mathrm{m}^{2}$ is stiff, $200-400 \mathrm{kN} / \mathrm{m}^{2}$ very stiff and greater than $400 \mathrm{kN} / \mathrm{m}^{2}$ indicates hard clay. From the study area: consistency of sample A is medium soft, while sample B is from medium soft to stiff, and sample $\mathrm{C}$ ranges from soft to medium soft.

Table 1. Summary of the preliminary analysis of soil samples

\begin{tabular}{||l|l|l|l|l|l|l||}
\hline $\begin{array}{l}\text { Sample } \\
\text { Code }\end{array}$ & $\begin{array}{l}\text { Specific } \\
\text { gravity }\end{array}$ & $\begin{array}{l}\text { Liquid } \\
\text { limit }(\boldsymbol{\%})\end{array}$ & $\begin{array}{l}\text { Plastic } \\
\text { limit }(\boldsymbol{\%})\end{array}$ & $\begin{array}{l}\text { Plasticity } \\
\text { index (\%) }\end{array}$ & $\begin{array}{l}\text { Natural } \\
\text { moisture } \\
\text { content (\%) }\end{array}$ & $\begin{array}{l}\text { Linear } \\
\text { shrinkage } \\
(\boldsymbol{\%})\end{array}$ \\
\hline A & 2.77 & 5.3 & 22.6 & 32.7 & 30.2 & 11.0 \\
\hline B & 2.74 & 52.0 & 24.3 & 27.7 & 28.8 & 11.5 \\
\hline C & 2.65 & & & & 29.5 & \\
\hline
\end{tabular}

Table 2. Summary of Atterbergs tests

\begin{tabular}{||l|l|l|l|l||}
\hline Sample Code & Saw dust ash percentage & Liquid limit (LL) \% & Plastic limit (PL)\% & Plastic index (PI) \% \\
\hline \multirow{5}{*}{ A } & $0 \%$ & 55.3 & 22.6 & 32.4 \\
\cline { 2 - 5 } & $2 \%$ & 53.7 & 23.0 & 30.7 \\
\cline { 2 - 5 } & $4 \%$ & 51.0 & 24.2 & 26.8 \\
\cline { 2 - 5 } & $6 \%$ & 47.4 & 25.4 & 22.1 \\
\cline { 2 - 5 } & $8 \%$ & 45.1 & 26.6 & 18.5 \\
\cline { 2 - 5 } & $10 \%$ & 44.2 & 27.4 & 16.8 \\
\hline \multirow{5}{*}{ B } & $0 \%$ & 52.0 & 24.3 & 16.8 \\
\cline { 2 - 5 } & $2 \%$ & 49.4 & 25.5 & 23.9 \\
\cline { 2 - 5 } & $4 \%$ & 45.5 & 26.7 & 18.8 \\
\cline { 2 - 5 } & $6 \%$ & 43.2 & 28.1 & 15.1 \\
\cline { 2 - 5 } & $8 \%$ & 39.3 & 29.5 & 6.4 \\
\cline { 2 - 5 } & $10 \%$ & 37.4 & 30.9 & \\
\hline
\end{tabular}

Table 3. Summary of compaction and CBR tests

\begin{tabular}{|c|c|c|c|c|}
\hline Sample code & Sawdust ash percentage & $\begin{array}{lll}\text { Optimum } & \text { moisture content } \\
(\mathrm{OMC}) \% & & \\
\end{array}$ & $\begin{array}{l}\text { Maximum dry density } \\
\left(\mathrm{Kg} / \mathrm{m}^{3}\right)\end{array}$ & CBR \\
\hline \multirow{6}{*}{ A } & $0 \%$ & 28.2 & 1456.0 & 3 \\
\hline & $2 \%$ & 27.7 & 1483.0 & 3 \\
\hline & $4 \%$ & 28.4 & 1463.0 & 7 \\
\hline & $6 \%$ & 29.2 & 1442.0 & 7 \\
\hline & $8 \%$ & 29.7 & 1421.0 & 6 \\
\hline & $10 \%$ & 30.1 & 1403 & 5.5 \\
\hline \multirow{6}{*}{ B } & $0 \%$ & 29.2 & 1785 & 11.5 \\
\hline & $2 \%$ & 23.6 & 1816 & 16.6 \\
\hline & $4 \%$ & 24.1 & 1796 & 14 \\
\hline & $6 \%$ & 24.7 & 1777 & 12 \\
\hline & $8 \%$ & 25.4 & 1756 & 10 \\
\hline & $10 \%$ & 26.2 & 1730 & 7 \\
\hline \multirow{6}{*}{$\mathrm{C}$} & $0 \%$ & 15.2 & 1978 & 34 \\
\hline & $2 \%$ & 14.6 & 2011 & 34.5 \\
\hline & $4 \%$ & 13.9 & 2031 & 30.5 \\
\hline & $6 \%$ & 14.4 & 2009 & 27.5 \\
\hline & $8 \%$ & 15.0 & 1984 & 23.5 \\
\hline & $10 \%$ & 15.8 & 1956 & 10 \\
\hline
\end{tabular}




\begin{tabular}{|c|c|c|c|}
\hline Sample code & Sawdust ash percentage & $\begin{array}{l}\text { Unconfined compressive strength (qu) } \\
\mathrm{kN} / \mathrm{m}^{2}\end{array}$ & $\begin{array}{l}\begin{array}{l}\text { Shear } \\
\mathrm{kN} / \mathrm{m}^{2}\end{array} \\
\text { Strength }\end{array}$ \\
\hline \multirow{6}{*}{ A } & $0 \%$ & 142.14 & 71.07 \\
\hline & $2 \%$ & 122.11 & 66.44 \\
\hline & $4 \%$ & 122.09 & 60.05 \\
\hline & $6 \%$ & 111.97 & 55.97 \\
\hline & $8 \%$ & 105.30 & 52.65 \\
\hline & $10 \%$ & 101.04 & 50.92 \\
\hline \multirow{6}{*}{ B } & $0 \%$ & 211.11 & 105.99 \\
\hline & $2 \%$ & 197.47 & 99.23 \\
\hline & $4 \%$ & 192.44 & 90.22 \\
\hline & $6 \%$ & 163.26 & 84.63 \\
\hline & $8 \%$ & 160.77 & 80.17 \\
\hline & $10 \%$ & 154.97 & 77.49 \\
\hline \multirow{6}{*}{$\mathrm{C}$} & $0 \%$ & 42.60 & 46.90 \\
\hline & $2 \%$ & 85.82 & 42.91 \\
\hline & $4 \%$ & 75.80 & 37.40 \\
\hline & $6 \%$ & 70.21 & 35.49 \\
\hline & $8 \%$ & 65.82 & 32.91 \\
\hline & $10 \%$ & 62.35 & 31.38 \\
\hline
\end{tabular}

\section{Conclusions}

1. Linear shrinkage, natural moisture content, optimum moisture content, maximum dry density, plasticity index, non-soaked CBR, specific gravity and unconfined compressive strength of the studied soils are optimally improved by adding saw dust ash.

2. The addition of saw dust ash makes sample A good sub- grade material, sample B good for sub -base, while sample $\mathrm{C}$ is not good for engineering purposes.

3. Optimum results can be achieved by adding $6 \%$ of saw dust ash as to the lateritic soils weight.

4. This study has revealed that saw dust satisfactorily acts as a cheap stabilizing agent for sub - grade and sub- base purposes in lateritic soil.

\section{References}

AMADI, AGAPITUS (2010): Evaluation of Changes in Index Properties of latentic soil Stabilized with Fly Ash Leonardo Electronic Journal of Practices and Technologies, Issue 17. pp. 69-78.

AMU, O.O., ORIGBEMIDE, A.R. AND SASEUN, E.O. (2010): Effects of dissolved Alum on the Geotechnical Properties of Lateritic soil for Road Construction. Research Journal of Applied Sciences, Engineering and Technology. Vol. 2(6) pp 543-546.

AMU, O.O., OGUNNIYI, S.A. AND OLADEJI O.O. (2011): Geotechnical Properties of Lateritic soil stabilized with sugar cane straw ash. American journal of Scientific and industrial Research, Pp. 323 -331.

ASPHALT INSTITUTE (1962): The Asphalt Handbook, Mary Land USA, 176p.

BS 1377 (1991): Methods of test for Civil Engineering Purposes. BS London.
DAS, B.M (2000): Fundamental of Geotechnical Engineering $4^{\text {th }}$ ed. Thomson Learning USA. Frias M, and Cement and Concrete Research.

GIDIGASU, M.D. (1983): Development of Specification for Tropical Gravels in Pavement Construction. Engineering Geology. Vol. 19, pp 213-240. http://dx.doi.org/10.1016/0013-7952(83)90004-2

JEGEDE, G. (2000): Effect of Soil Properties on Pavement Failures along the F209 Highway at Ado Ekiti, South Western Nigeria. Construction and Building Materials. Vol. 14, pp 311-315. http://dx.doi.org/10.1016/S0950-0618(00)00033-7

OKAFOR, F.O. AND OKONKWO, U.N. (2009): Effects of Rice Husk ash on some Geotechnical Properties of Lateritic soil. Leonardo Electronic Journal of Practices and Technologies, Issue 15, pp 67-74.

OKUNADE, E.A. (2010): Geotechnical Properties of some coal Fly Ash Stabilized South Western Nigeria Latentic soil. Modern Applied Sciences. Vol. 4, No 12, pp. 66-73.

OLORUNTOLA, M.O., ADEYEMI, G.O AND ODUNEYE, O.C. (2008) :Comparative study of the Influence of Cement and lime Stabilization on Geotechnical Properties of Latentic soil Derived from Pegmatite in AgoIwoye, Southwestern Nigeria. Journal of Mining and Geology. Vol. 44(1), pp. 95-105. http://dx.doi.org/10.4314/jmg.v44i1.18887

RAHAMAN, M.A. (1976): Review of basement Geology of Southwestern Nigeria, In C.A. Kogbe, (ed) Geology Of Nigeria. Elizabethan publishing co. Lagos, pp, $41-58$.

RAHAMAN, M.A. (1988): Benin - Nigeria Geotraverse, International Meeting on Proterozoic Geology and Tectonic of High - Grade Nigeria.. Terrains. Program Lecture Series Project 215, PP 1 -36.

\begin{tabular}{|l|}
\hline Thompson Henry Tolulope Ogunribido - \\
Department of Geology, Adekunle Ajasin University, \\
Akungba \\
Akoko, Nigeria \\
E-mail: $\quad$ ogunribido_henry @yahoo.com \\
\hline
\end{tabular}




\section{Geotechninės pjuvenų pelenų savybės Nigerijos lateritiniam dirvožemiui stabilizuoti}

\section{Thompson Henry Tolulope Ogunribido}

Geologijos katedra, Adekunle Ajastin universitetas, Nigerija

(gauta 2011 m. gruodžio mèn., priimta spaudai 2012m. birželio mèn.)

Tyrimo tikslas - ivvertinti pjuvenų pelenų poveiki geotechninėms dirvos savybėms trijose Pietvakarių Nigerijos vietovėse. Tyrimų rezultatai parode, kad pjuvenų pelenai pagerino geotechnines bandinių savybes. Todèl straipsnyje teigiama, kad pjuvenų pelenai gali būti naudojami lateritiniam dirvožemiui stabilizuoti. 